\title{
Exploring Content Game Elements to Support Gamification Design in Educational Systems: Narrative and Storytelling
}

\author{
Paula T. Palomino ${ }^{1}$, Armando M. Toda ${ }^{1,2}$, Wilk Oliveira ${ }^{1}$, Luiz Rodrigues ${ }^{1}$, \\ Alexandra I. Cristea ${ }^{2}$, Seiji Isotani ${ }^{1}$ \\ ${ }^{1}$ Institute of Mathematics and Computer Science - University of São Paulo (ICMC-USP) \\ 400 Trabalhador São-carlense Avenue São Carlos, SP 13566-590 - Brazil. \\ ${ }^{2}$ Department of Computer Science - University of Durham - Durham, U.K. \\ \{paulatpalomino, armando.toda, wilk.oliveira, lalrodrigues\}@usp.br \\ alexandra.i.cristea@durham.ac.uk, sisotani@icmc.usp.br
}

\begin{abstract}
Several studies on gamification applied to educational systems aim at encouraging students to do certain tasks and improving their learning. According to the literature, most gamification frameworks are structural (e.g. scoring systems, ranking, etc.), with few content-related frameworks. To the best of our knowledge, there is no narrative framework available. Therefore this paper analyses data obtained from a survey about the students' preferred game elements in an educational context, with focus on Association Rules found concerning Narrative and Storytelling elements. We show that Narrative and Storytelling are tightly related and provide insights of their use in groups with other game elements, enabling the creation of gamified strategies based on these aspects.
\end{abstract}

\section{Introduction}

From their inception to the current day, implementation and use of information technologies (ITs) have undergone substantial changes in the way in which they are represented in a great variety of areas, including learning [Preece et al. 2015, Jenkins 2006]. Specifically in the latter learning context, one of these changes refers to the increasing use of gamification (defined as the use of game elements outside of a game). Concretely, gamification is mostly used to engage and motivate students in the learning process, as well as improving their experience [Deterding et al. 2011a, Seaborn and Fels 2014, Hamari et al. 2014].

Gamified education has already achieved positive results [Borges et al. 2014, Deterding et al. 2011b], when used concomitantly with traditional methodologies, or as a complement to virtual applications. According to [Smith-Robbins 2011], one can observe some of these elements already present in the traditional methodology. Traditional teaching can be compared to the process of gamification, through a parallel between concepts found in the traditional model, such as grades, groups, and degrees, and game elements such as points, levels, and achievements.

Nevertheless, in spite of its advantages, gamification interventions might still sometimes fail to improve students' motivation [Toda et al. 2018]. Thus, we have researched ways to improve the current gamification landscape. One way to provide better gamification recommendations, explored in this paper, is to rely on elements different 
VIII Congresso Brasileiro de Informática na Educação (CBIE 2019)

Anais do XXX Simpósio Brasileiro de Informática na Educação (SBIE 2019)

from the traditional PBL approaches (Point-Badge-Leaderboard) [Bogost 2014]. The reason is that these elements are more related to structural gamification and are not concerned with the content of applications [Kapp 2012]. According to [Palomino et al. 2019], Narrative and Storytelling are elements that are concerned with both the content and immersive experiences in gamified systems, but have nevertheless been neglected/forgotten by a majority of studies in the field. To address this gap, we aim at answering the following research question "How can we use Storytelling and Narrative alongside other gamification elements to improve students engagement?". To answer this question, we propose a data-driven study based on a previous work developed by [Toda et al. 2019b], where they explored the acceptance of gamified strategies. Our main contribution is a new set of recommendations based on the group of preferred game elements that can be used alongside Narrative and Storytelling elements, by teachers and instructors.

\section{Background and Related Work}

\subsection{On the Concepts of Narrative, Story and Storytelling}

Here we consider the concepts of the game elements Narrative and Storytelling, relating both of them with the concept of "story", from the perspective of gamification design, and specifically, gamification design of educational systems. The act of telling stories is as old as humanity itself. According to [Ricoeur 2010], one of the explanations of why human beings need to tell stories is connected to the relationship between time and narration [Augustine 1876]. A narrative is a sequence of events transmitted by an individual. This sequence may undergo modifications of quantitative or qualitative nature, changing, e.g. the way it is told, i.e. the storytelling. A narrative can also fulfill a calming function and, in this sense, it is crucial in its role as a game element related to motivation and purpose [Palomino et al. 2019].

According to [Salen et al. 2004], there are two types of narrative that are concerned with player experience: embedded and emergent. The former is the story inserted in the game system, which confers meaning and context to the rules. Without it, actions simply inherent in the interaction mechanics could be abstract and devoid of purpose. In this way, the embedded narrative aims to give a significant stake to the player through its plot, as a premise to story, characters and sequence of events, which render a dramatic unity to the player's interactions and journey. As for the latter, it is the story that is created from the interactive experience of the player. Its base is also planned by the game designer, but its unfolding is often not. This occurs due to the events created that are a natural consequence of the player's freedom of choice in the face of the game mechanics and their experience as a user [Salen et al. 2004].

As for gamification studies, [Palomino et al. 2019] defines narrative as the sequence of events that guides the users towards a defined goal, which can be supported by storytelling. The act of narrating stories comes together with a purpose of meaning, and constant transformation, by establishing a dialogue with the receptor. By understanding the act of teaching, amongst other things as an act of communication from the teacher to the student, we can see why the elements Narrative and Storytelling are specifically important to the education domain. 
VIII Congresso Brasileiro de Informática na Educação (CBIE 2019)

Anais do XXX Simpósio Brasileiro de Informática na Educação (SBIE 2019)

\subsection{Related Works}

As we can observe from the background, Narrative and Storytelling have been explored by humanity for a long time, and their importance understood. Nevertheless, few works focused on exploring the concept of Narrative or Storytelling in games applied to education. One example is [Champagnat et al. 2010], who dealt directly with the storytelling concept applied to learning. The authors presented a variation of Campbell's Hero Journey [Campbell 2008] exclusively for interactive storytelling and show how this model can be used in an educational context using serious games.

Following, [Adams et al. 2012] stated that the narrative hypothesis deals with how a story or narrative element can impact on learning outcomes, suggesting that when considering learning from texts, if the information is in a narrative genre style, it is better learned and retained than the information from an expository or descriptive text [Landers et al. 2017]. Although this narrative view is restricted to text literature, it provides insights into how the narrative element can be applied to improve the learning.

Next, the theory of gamified learning [Landers 2014] presented a model in which game elements could be used in isolation or in limited combination, to gamify the instructional process aiming to improve learning. Each game element should be linked to specific behavioral, motivational or attitudinal outcomes that connect with learning outcomes, in order to make gamification in education effective [Landers et al. 2017].

[Chauvin et al. 2015] presented a study directed to supporting player-triggered narrative processes in game emergent narratives, working with methods such as procedural content generation [Togelius et al. 2011, Hendrikx et al. 2013] to increase the number of possible situations the player encounters. Although it is focused towards games that are not educational and do not deal with gamification, the aspects covered by the study (i.e., support the generation of emergent narrative using "Interpretation Engines" and Procedural Content Generation techniques) can point to a practical way to use narratives for gamification in educational environments.

Finally, [Toda et al. 2019b] designed an approach to identify gamification patterns using Association Rule Mining (ARM), by applying surveys of people who play games and analysing their preferences. Although showing interesting initial results, the authors do not specifically explore in-depth the concepts of Narrative or Storytelling, and instead look into the genders' influence over general gamification patterns.

Concluding, there are no studies, to the best of our knowledge, which focus on designing and applying the concepts of Narrative and Storytelling to gamified systems through a data-driven approach. This gap shows that it is important to conduct deeper studies and analyses into this area, especially since it can potentially contribute to increase the student motivation in the learning process.

\section{Methods and Tools}

To conduct our study, we replicated the methods used in [Toda et al. 2019b], which consisted of three phases: Data collection, Analysis and Summary.The first phase consists in applying a survey designed in [Toda et al. 2019a] asking which are the game ele- 
VIII Congresso Brasileiro de Informática na Educação (CBIE 2019)

Anais do XXX Simpósio Brasileiro de Informática na Educação (SBIE 2019)

ments $(\mathrm{N}=21$ game elements) most preferred by students 1 . To recruit users, we used social networks. In total, we obtained 430 answers. To verify the reliability of the questionnaire, we applied Cronbach's alpha and obtained $\alpha=0.81$ (high reliability) [Tavakol and Dennick 2011].

This population is composed of Brazillian individuals, where 347 consider themselves as males, 80 females, 1 agender, 1 non-binary and 1 transgender. The average age is 26.9 years $(\mathrm{SD}=8.2)$, with most individuals between $15-34$ years $(82.6 \%)$. This population has an experience in playing games of approximately 17.9 years (with relatively high variance, $\mathrm{SD}=7$ ) and play an average of 16.6 hours per week (with very high variance, $\mathrm{SD}=17.2)$. This population also prefer RPG genre $(43.3 \%)$ and single player games $(68.4 \%)$.

Secondly, we analysed the data through Association Rule Mining (ARM) [Manimaran and Velmurugan 2015a], which is a method to discover patterns within data based on the frequency of the items. ARM uses the support (frequency) of an item in the dataset, and creates rules based on logical sentences (e.g., $A \rightarrow B)$ [Agrawal et al. 1993]. These rules are measured through their confidence and lift [Manimaran and Velmurugan 2015b]. To conduct the analyses and report we analyse rules focused on Narrative and Storytelling with high confidence ( $>0.8)$ and lift ( 1.5). These analyses were made in $\mathrm{R}$ version 3.4 .3 with packages arules and arulesviz. After extracting the rules, we evaluated and analysed them with specialists in the field of gamification and aimed at creating the recommendations in a way that could be understood by teachers and instructors.

\section{Results and Discussion}

This section introduces and interprets the results. First, when we analysed the element of Narrative, we found a total of 43 rules $\left.($ Table 1$)\right|^{2}$ that met the predefined conditions, as can be seen in Figure 1. As per Table 1, we identified the following: $i$ ) users who consider the elements of Cooperation, Objectives and Storytelling as totally important will prefer the element of Narrative with the same intensity. This suggests that, in an educational context, the gamified content should be presented with clear objectives and description (as in Storytelling) and their tasks should be able to be carried out cooperatively. As a result of this instructional design, the students would also look for their liberty of choice, constructing their own way (as in Narrative); ii) other association rule grouped Puzzles, Stats and Storytelling with the same importance as Narrative $(=5)$. This suggests that students who favour Narrative associated with Storytelling also expect mental challenges (Puzzles) and real time inputs (Stats). In instructional design terms, this means that the content should be presented in a challenging way, with a subjective purpose (such as via a story), with clear information about the steps and a logical myriad of options and paths the student could choose to finish the task; iii) the group composed by Puzzle, Sensation and Storytelling indicates that the students could benefit from instructional design based on a story that should be told in a certain way to evoke sensations and experiences, while maintaining the challenge and logical order of events coming from the students' choices;

\footnotetext{
${ }^{1}$ The survey uses a Likert scale [Tavakol and Dennick 2011] from 1 (where they do not think the game element is important to them) to 5 (where they think the element is really important to them). More details can be seen in [Toda et al. 2019a].

${ }^{2}$ The Consequent Rules - right-hand-side (RHS) - are, in all cases, Narrative $=5$.
} 
VIII Congresso Brasileiro de Informática na Educação (CBIE 2019)

Anais do XXX Simpósio Brasileiro de Informática na Educação (SBIE 2019)

iv) the group formed by Progression, Puzzles and Storytelling is similar to the previous one, but these students favour their sense of advancing in detriment of their subjective sensations; and $v$ ) the group composed by Objectives, Puzzles, Sensation and Storytelling expands the previous analysis and provides us with a possible cause for the uncertain improvement we gain with the use of exclusively structural elements in gamified educational systems. By bringing together the elements of Objectives and Puzzles (structure) with Sensation and Storytelling (content), associated with Narrative, we can infer that students, while wishing to have mental challenges and clear goals to follow, want to feel themselves sensorially and mentally immersed in the task; vi) the group composed by Progression, Objectives, Puzzles and Storytelling show us that even in the case in which the students' preference lays with structural game elements (Progression, Objectives and Puzzles), the addition of Storytelling associated with Narrative is equally important in the tailoring of the activity, for a better result.

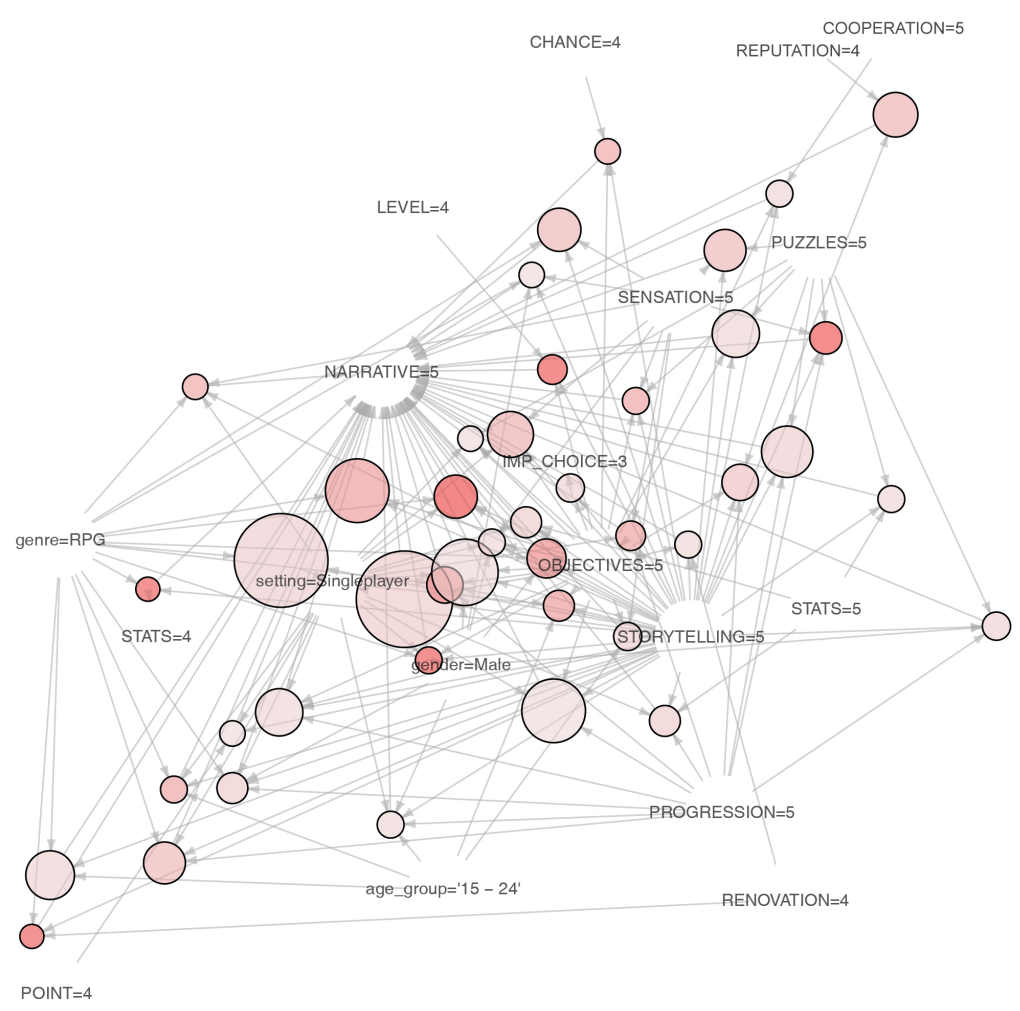

Figure 1. Graph for 43 Narrative Rules

The same process was done with the Storytelling element, where we found 66 rules Table 2 ${ }^{3}$, using the same predefined conditions, as can be seen in Figure 2. From this, we can infer that: $i$ ) The elements of Rarity and Narrative are tied with Storytelling, suggesting that in educational contexts, the tasks should have some kind of collectible reward related to how the students solve the task and the story/content to be learned; ii) another group composed by Progression, Rarity and Narrative, associated with Storytelling, suggests an instructional design based on the previous analysis, but with the addition of the Progression element (e.g., letting the students know where they are in the content; how much they progressed on the task at hand; and how much they still have

\footnotetext{
${ }^{3}$ The Consequent Rules - right-hand-side (RHS) - are, in all cases, Storytelling=5.
} 
VIII Congresso Brasileiro de Informática na Educação (CBIE 2019)

Anais do XXX Simpósio Brasileiro de Informática na Educação (SBIE 2019)

Table 1. RHS Narrative Rules

\begin{tabular}{|c|c|c|c|}
\hline Antecedent Rules - left-hand-side (LHS) & \begin{tabular}{|l|} 
Sup. \\
\end{tabular} & Conf. & Lift \\
\hline$\{$ REPUTATION=4,STORYTELLING $=5\}$ & 0.13 & 0.95 & 1.52 \\
\hline$\{$ COOPERATION=5,OBJECTIVES=5,STORYTELLING=5 $\}$ & 0.10 & 0.93 & 1.50 \\
\hline$\{$ OBJECTIVES $=5$, CHANCE $=4$, STORYTELLING $=5\}$ & 0.10 & 0.95 & 1.53 \\
\hline$\{$ setting=Singleplayer,POINT=4,STORYTELLING $=5\}$ & 0.10 & 0.93 & 1.50 \\
\hline$\{$ PUZZLES $=5$, STATS $=5$, STORYTELLING $=5\}$ & 0.10 & 0.93 & 1.50 \\
\hline$\{$ OBJECTIVES=5,PUZZLES=5,STORYTELLING=5 $\}$ & 0.13 & 0.93 & 1.50 \\
\hline$\{$ PUZZLES $=5$, sensation $=5$, STORYTELLING $=5\}$ & 0.13 & 0.94 & 1.52 \\
\hline$\{$ PROGRESSION=5,PUZZLES=5,STORYTELLING $=5\}$ & 0.14 & 0.94 & 1.50 \\
\hline$\{$ genre $=$ RPG,STATS $=4$, STORYTELLING $=5\}$ & 0.10 & 0.97 & 1.56 \\
\hline$\{$ LEVEL=4,OBJECTIVES=5,STORYTELLING=5 $\}$ & 0.10 & 0.97 & 1.57 \\
\hline$\{$ genre $=$ RPG,RENOVATION $=4$, STORYTELLING $=5\}$ & 0.10 & 0.97 & 1.56 \\
\hline$\{$ RENOVATION=4,OBJECTIVES=5,STORYTELLING=5 $\}$ & 0.10 & 0.93 & 1.50 \\
\hline$\{$ OBJECTIVES=5,IMP_CHOICE $=3$, STORYTELLING $=5\}$ & 0.10 & 0.93 & 1.50 \\
\hline$\{$ age_group='15 - 24',genre=RPG,STORYTELLING=5 & 0.14 & 0.93 & 1.50 \\
\hline$\{$ genre $=$ RPG,OBJECTIVES $=5$, STORYTELLING $=5\}$ & 0.16 & 0.96 & 1.54 \\
\hline$\{$ genre $=$ RPG,sensation $=5$, STORYTELLING $=5\}$ & 0.13 & 0.95 & 1.52 \\
\hline$\{$ genre $=$ RPG,setting $=$ Singleplayer,STORYTELLING $=5\}$ & 0.21 & 0.94 & 1.50 \\
\hline$\{$ setting=Singleplayer,OBJECTIVES=5,STORYTELLING $=5\}$ & 0.22 & 0.94 & 1.51 \\
\hline$\{$ OBJECTIVES $=5$, PUZZLES $=5$, sensation $=5$, STORYTELLING $=5\}$ & 0.10 & 0.95 & 1.53 \\
\hline$\{$ PROGRESSION=5,OBJECTIVES=5,PUZZLES=5,STORYTELLING=5 $\}$ & 0.12 & 0.94 & 1.51 \\
\hline$\{$ setting=Singleplayer,OBJECTIVES=5,PUZZLES=5,STORYTELLING=5 $\}$ & 0.10 & 0.93 & 1.50 \\
\hline$\{$ PROGRESSION=5,PUZZLES=5, sensation=5,STORYTELLING=5 $\}$ & 0.11 & 0.98 & 1.57 \\
\hline$\{$ gender=Male,PROGRESSION=5,PUZZLES=5,STORYTELLING=5 $\}$ & 0.10 & 0.93 & 1.50 \\
\hline$\{$ setting=Singleplayer,OBJECTIVES=5,STATS=5,STORYTELLING=5 $\}$ & 0.11 & 0.94 & 1.51 \\
\hline$\{$ setting $=$ Singleplayer,PROGRESSION=5,STATS $=5$, STORYTELLING $=5\}$ & 0.11 & 0.94 & 1.51 \\
\hline$\{$ age_group='15 - 24',genre=RPG,setting=Singleplayer,STORYTELLING=5 & 0.10 & 0.95 & 1.53 \\
\hline$\{$ genre $=$ RPG,PROGRESSION=5,OBJECTIVES $=5$, STORYTELLING $=5\}$ & 0.12 & 0.96 & 1.54 \\
\hline$\{$ genre=RPG,setting=Singleplayer,OBJECTIVES=5,STORYTELLING=5 & 0.13 & 0.98 & 1.57 \\
\hline$\{$ gender=Male,genre=RPG,OBJECTIVES=5,STORYTELLING=5 $\}$ & 0.12 & 0.96 & 1.54 \\
\hline$\{$ genre=RPG,setting=Singleplayer,sensation=5,STORYTELLING=5 $\}$ & 0.10 & 0.95 & 1.53 \\
\hline$\{$ gender $=$ Male,genre $=$ RPG,sensation $=5$, STORYTELLING $=5\}$ & 0.10 & 0.93 & 1.50 \\
\hline$\{$ genre=RPG,setting=Singleplayer,PROGRESSION=5,STORYTELLING=5 $\}$ & 0.13 & 0.94 & 1.52 \\
\hline$\{$ age_group='15 - 24',OBJECTIVES=5,sensation=5,STORYTELLING=5 $\}$ & 0.10 & 0.93 & 1.50 \\
\hline$\{$ age_group='15 - 24',setting=Singleplayer,OBJECTIVES=5,STORYTELLING=5 & 0.11 & 0.96 & 1.54 \\
\hline$\{$ setting $=$ Singleplayer,OBJECTIVES $=5$, sensation $=5$, STORYTELLING $=5\}$ & 0.13 & 0.95 & 1.52 \\
\hline$\{$ setting=Singleplayer,PROGRESSION=5,OBJECTIVES=5,STORYTELLING=5 & 0.16 & 0.93 & 1.50 \\
\hline$\{$ gender=Male,setting=Singleplayer,OBJECTIVES=5,STORYTELLING=5 $\}$ & 0.17 & 0.93 & 1.50 \\
\hline$\{$ gender=Male,genre=RPG,setting=Singleplayer,OBJECTIVES=5,STORYTELLING=5 $\}$ & 0.10 & 0.97 & 1.56 \\
\hline$\{$ gender=Male,genre=RPG,setting=Singleplayer,PROGRESSION=5,STORYTELLING=5 $\}$ & 0.11 & 0.94 & 1.51 \\
\hline$\{$ gender=Male,age_group='15 - 24',setting=Singleplayer,PROGRESSION=5,STORYTELLING=5 $\}$ & 0.10 & 0.93 & 1.50 \\
\hline$\{$ setting=Singleplayer,PROGRESSION=5,OBJECTIVES $=5$,sensation=5,STORYTELLING=5 $\}$ & 0.10 & 0.95 & 1.53 \\
\hline$\{$ gender=Male,setting=Singleplayer,OBJECTIVES=5,sensation=5,STORYTELLING=5 $\}$ & 0.10 & 0.93 & 1.50 \\
\hline$\{$ gender=Male,setting=Singleplayer,PROGRESSION=5,OBJECTIVES=5,STORYTELLING=5 $\}$ & 0.13 & 0.93 & 1.50 \\
\hline
\end{tabular}

to do to finish it); iii) the group formed by Cooperation, Objectives and Narrative, associated with Storytelling, can be analysed in the same way as the first analysis on the Table 1's information; moreover, its existence shows that the relation between Narrative and Storytelling is bi-directional (e.g., people who like Narrative also like Storytelling and vice-versa); $i v$ ) the group composed of Progression, Objectives, Novelty and Narrative adds a new element as a preference, suggesting that users would like the content to be updated and fresh, in order to hold their interest; and $v$ ) the group formed by Level, Objectives, Sensation and Narrative adds for the first time the Level element, meaning that content and structural elements can co-exist in harmony in gamified educational systems. People from these group favours clear goals and a measure of hierarchical layers present in the environment, as well as the content to be presented inside a context, arising sensations and, consequently, meaning.

Other more general insights include the fact that Time Pressure is not considered important by these users, that they favours the RPG game genre and that most of them are males and between 15-24 years old. These are demographic information relevant to plan future instructional designs. In short, whilst different people have different preferences, 


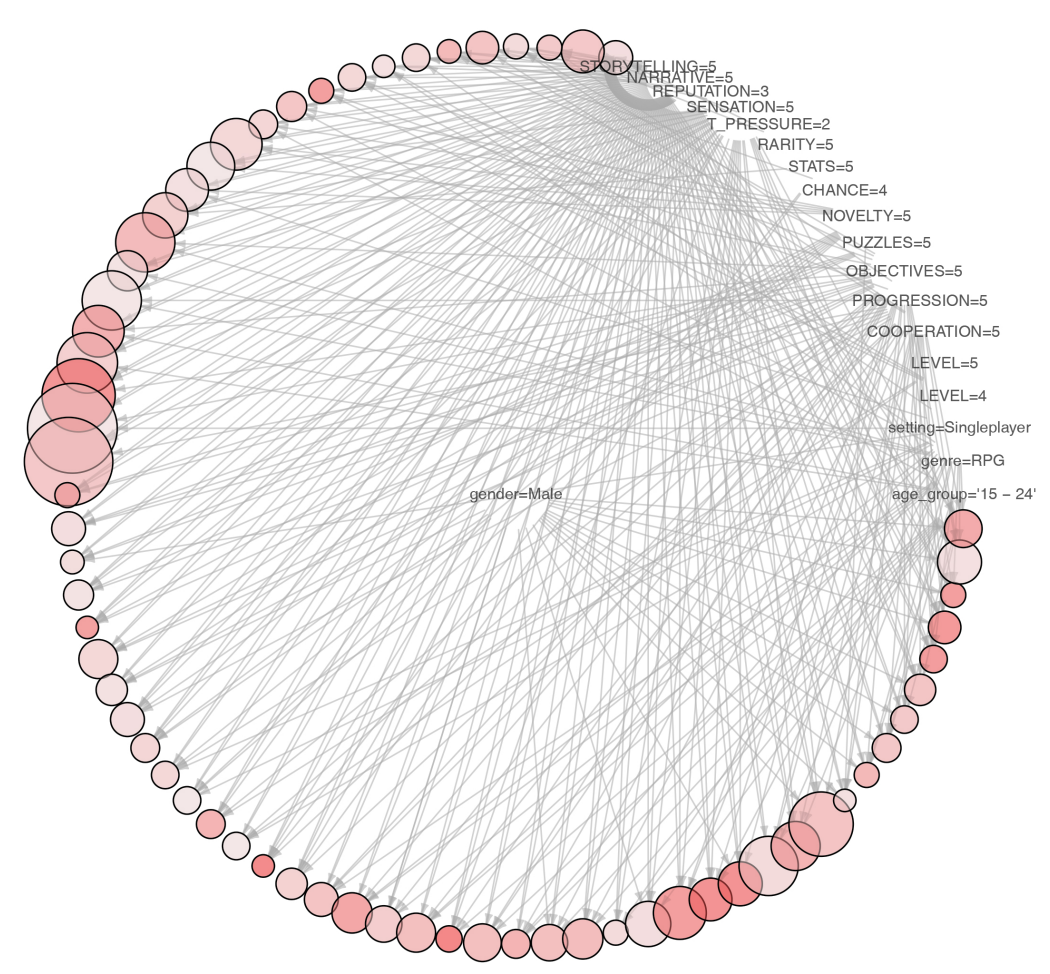

Figure 2. Graph for the 66 Storytelling Rules

it possible to identify and cluster these groups to ultimately tailor an educational system to suit these varied tastes. This is one of the reasons why it is necessary to deepen the studies in the recent field of data-driven education, as through this approach it is possible to reach a higher level of specificity and depth regarding these personal preferences of each student.

As far as the technical limitations of this study are concerned, only rules based on two elements and with high limits were considered (since this is a limitation of the ARM algorithm itself). Our sample of students also belongs only to Brazil, and these results have not yet been validated empirically.

\section{Conclusions}

The purpose of this paper was to analyse the importance of the game elements Narrative and Storytelling for students (represented by the user sample that answered the survey that aimed to collect their game element preferences in educational contexts), as well as the relationships between those elements (as antecedent and consequent) and other game elements, categorised by the taxonomy proposed by [Toda et al. 2019a]. For that, ARM techniques were used, which, within the data-driven approach applied to educational contexts, are quite recent and still need more studies. Our main contribution was to provide insights and strategies to support the design of gamified content educational environments and/or frameworks, based mainly on the strong connection we found between Narrative and Storytelling elements.

For future works we intend to use these strategies to design a narrative gamification framework, focused on the education domain. We intend to test and validate their use in an empirical experiment, in order to provide solid guidelines that could be used in the 
VIII Congresso Brasileiro de Informática na Educação (CBIE 2019)

Anais do XXX Simpósio Brasileiro de Informática na Educação (SBIE 2019)

Table 2. RHS Storytelling Rules

\begin{tabular}{|c|c|c|c|}
\hline Antecedent Rules - left-hand-side (LHS) & Sup. & Conf. & Lift \\
\hline$\{$ RARITY $=5$, NARRATIVE $=5\}$ & 0.12 & 0.89 & 1.52 \\
\hline$\{$ T_PRESSURE $=2$, NARRATIVE $=5\}$ & 0.13 & 0.92 & 1.56 \\
\hline$\{$ PROGRESSION=5,RARITY=5,NARRATIVE $=5\}$ & 0.10 & 0.91 & 1.56 \\
\hline$\{$ COOPERATION=5,OBJECTIVES=5,NARRATIVE=5 $\}$ & 0.10 & 0.9 & 1.52 \\
\hline$\{$ COOPERATION $=5$,sensation $=5$,NARRATIVE $=5\}$ & 0.11 & 0.92 & 1.57 \\
\hline$\{$ OBJECTIVES $=5, \mathrm{CHANCE}=4, \mathrm{NARRATIVE}=5\}$ & 0.10 & 0.93 & 1.59 \\
\hline$\{$ setting=Singleplayer,REPUTATION=3,NARRATIVE $=5\}$ & 0.10 & 0.90 & 1.53 \\
\hline$\{$ genre=RPG,LEVEL=4,NARRATIVE $=5\}$ & 0.1 & 0.89 & 1.52 \\
\hline$\{$ LEVEL $=4$, OBJECTIVES $=5$, NARRATIVE $=5\}$ & 0.10 & 0.90 & 1.53 \\
\hline$\{$ LEVEL $=4$, PROGRESSION $=5$, NARRATIVE $=5\}$ & 0.10 & 0.95 & 1.62 \\
\hline$\{$ genre=RPG,NOVELTY=5,NARRATIVE $=5\}$ & 0.11 & 0.92 & 1.57 \\
\hline$\{$ age_group='15 - 24',NOVELTY=5,NARRATIVE=5 & 0.11 & 0.90 & 1.53 \\
\hline$\{$ OBJECTIVES $=5$, NOVELTY $=5$, NARRATIVE $=5\}$ & 0.15 & 0.90 & 1.53 \\
\hline$\{$ NOVELTY=5,sensation=5,NARRATIVE $=5\}$ & 0.14 & 0.88 & 1.50 \\
\hline$\{$ setting $=$ Singleplayer,NOVELTY $=5$, NARRATIVE $=5\}$ & 0.13 & 0.89 & 1.51 \\
\hline$\{$ STATS $=5$, sensation $=5$, NARRATIVE $=5\}$ & 0.14 & 0.91 & 1.54 \\
\hline$\{$ genre $=$ RPG,OBJECTIVES $=5$, NARRATIVE $=5\}$ & 0.16 & 0.93 & 1.58 \\
\hline$\{$ genre $=$ RPG,sensation $=5$, NARRATIVE $=5\}$ & 0.13 & 0.89 & 1.51 \\
\hline$\{$ genre=RPG,PROGRESSION=5,NARRATIVE $=5\}$ & 0.167 & 0.88 & 1.51 \\
\hline$\{$ age_group='15 - 24',OBJECTIVES=5,NARRATIVE=5 $\}$ & 0.15 & 0.94 & 1.60 \\
\hline$\{$ age_group='15 - 24',sensation=5,NARRATIVE $=5\}$ & 0.16 & 0.91 & 1.55 \\
\hline$\{$ OBJECTIVES $=5$, sensation $=5$, NARRATIVE $=5\}$ & 0.19 & 0.96 & 1.64 \\
\hline$\{$ setting=Singleplayer,OBJECTIVES=5,NARRATIVE $=5\}$ & 0.22 & 0.88 & 1.51 \\
\hline$\{$ PROGRESSION $=5$, sensation $=5$, NARRATIVE $=5\}$ & 0.22 & 0.92 & 1.56 \\
\hline$\{$ OBJECTIVES=5,PUZZLES=5, sensation=5,NARRATIVE=5 $\}$ & 0.10 & 0.93 & 1.59 \\
\hline$\{$ PROGRESSION=5,OBJECTIVES=5,PUZZLES=5,NARRATIVE=5 $\}$ & 0.12 & 0.89 & 1.52 \\
\hline$\{$ setting=Singleplayer,OBJECTIVES=5,PUZZLES=5,NARRATIVE=5 $\}$ & 0.10 & 0.89 & 1.52 \\
\hline$\{$ PROGRESSION=5,PUZZLES=5, sensation=5,NARRATIVE=5 $\}$ & 0.11 & 0.89 & 1.51 \\
\hline$\{$ OBJECTIVES=5,NOVELTY=5, sensation=5,NARRATIVE=5 $\}$ & 0.1 & 0.95 & 1.62 \\
\hline$\{$ PROGRESSION=5,OBJECTIVES=5,NOVELTY=5,NARRATIVE=5 $\}$ & 0.13 & 0.90 & 1.53 \\
\hline$\{$ gender=Male,OBJECTIVES=5,NOVELTY=5,NARRATIVE=5 $\}$ & 0.11 & 0.89 & 1.51 \\
\hline$\{$ PROGRESSION=5,NOVELTY=5, sensation=5,NARRATIVE=5 $\}$ & 0.12 & 0.89 & 1.52 \\
\hline$\{$ gender=Male,NOVELTY $=5$, sensation $=5$, NARRATIVE $=5\}$ & 0.11 & 0.90 & 1.53 \\
\hline$\{$ setting=Singleplayer,PROGRESSION=5,NOVELTY=5,NARRATIVE=5 & 0.10 & 0.90 & 1.53 \\
\hline$\{$ gender=Male,setting=Singleplayer,NOVELTY=5,NARRATIVE=5 $\}$ & 0.10 & 0.88 & 1.50 \\
\hline$\{$ LEVEL=5,OBJECTIVES=5, sensation=5,NARRATIVE $=5\}$ & 0.11 & 0.94 & 1.59 \\
\hline$\{$ setting=Singleplayer,LEVEL=5,OBJECTIVES=5,NARRATIVE=5 $\}$ & 0.10 & 0.88 & 1.50 \\
\hline$\{$ OBJECTIVES=5,STATS $=5$, sensation=5,NARRATIVE $=5\}$ & 0.1 & 0.97 & 1.66 \\
\hline$\{$ PROGRESSION=5,STATS=5, sensation=5,NARRATIVE $=5\}$ & 0.11 & 0.90 & 1.54 \\
\hline$\{$ genre=RPG,PROGRESSION=5,OBJECTIVES=5,NARRATIVE=5 $\}$ & 0.12 & 0.92 & 1.57 \\
\hline$\{$ genre=RPG,setting=Singleplayer,OBJECTIVES=5,NARRATIVE $=5\}$ & 0.13 & 0.95 & 1.61 \\
\hline$\{$ gender $=$ Male,genre=RPG,OBJECTIVES $=5$, NARRATIVE $=5\}$ & 0.12 & 0.91 & 1.55 \\
\hline$\{$ genre=RPG,setting=Singleplayer,PROGRESSION=5,NARRATIVE=5 $\}$ & 0.13 & 0.93 & 1.58 \\
\hline$\{$ age_group='15 - 24',OBJECTIVES=5, sensation=5,NARRATIVE=5 $\}$ & 0.10 & 0.97 & 1.66 \\
\hline$\{$ age_group='15 - 24',PROGRESSION=5,OBJECTIVES=5,NARRATIVE=5 & 0.12 & 0.93 & 1.58 \\
\hline$\{$ age_group='15 - 24',setting=Singleplayer,OBJECTIVES=5,NARRATIVE=5 & 0.11 & 0.94 & 1.59 \\
\hline$\{$ gender=Male,age group='15 - 24',OBJECTIVES=5,NARRATIVE=5 & 0.12 & 0.93 & 1.58 \\
\hline$\{$ age_group='15 - 24',PROGRESSION=5, sensation=5,NARRATIVE=5 & 0.13 & 0.93 & 1.58 \\
\hline$\{$ age_group='15 - 24',setting=Singleplayer,sensation=5,NARRATIVE=5 $\}$ & 0.10 & 0.9 & 1.52 \\
\hline$\{$ gender=Male,age_group=' $15-24$ ',sensation=5,NARRATIVE=5 $\}$ & 0.14 & 0.89 & 1.52 \\
\hline$\{$ PROGRESSION $=5$, OBJECTIVES $=5$, sensation $=5$, NARRATIVE $=5\}$ & 0.15 & 0.95 & 1.62 \\
\hline$\{$ setting=Singleplayer,OBJECTIVES $=5$,sensation=5,NARRATIVE=5 $\}$ & 0.13 & 0.96 & 1.64 \\
\hline$\{$ gender $=$ Male,OBJECTIVES=5, sensation=5,NARRATIVE $=5\}$ & 0.13 & 0.96 & 1.64 \\
\hline$\{$ setting=Singleplayer,PROGRESSION=5,OBJECTIVES=5,NARRATIVE=5 $\}$ & 0.16 & 0.9 & 1.52 \\
\hline$\{$ setting=Singleplayer,PROGRESSION=5, sensation=5,NARRATIVE=5 $\}$ & 0.14 & 0.94 & 1.59 \\
\hline$\{$ gender=Male,PROGRESSION=5, sensation $=5$,NARRATIVE $=5\}$ & 0.17 & 0.92 & 1.57 \\
\hline$\{$ gender $=$ Male,PROGRESSION=5,OBJECTIVES=5,NOVELTY=5,NARRATIVE=5 $\}$ & 0.1 & 0.89 & 1.52 \\
\hline$\{$ gender=Male,genre=RPG,setting=Singleplayer,OBJECTIVES=5,NARRATIVE=5 & 0.10 & 0.93 & 1.59 \\
\hline$\{$ gender $=$ Male,genre=RPG,setting $=$ Singleplayer,PROGRESSION=5,NARRATIVE $=5\}$ & 0.11 & 0.92 & 1.56 \\
\hline \{gender=Male,age_group='15 - 24',PROGRESSION=5,OBJECTIVES=5,NARRATIVE=5 & 0.10 & 0.92 & 1.56 \\
\hline$\{$ gender=Male,age_group='15 - 24',PROGRESSION=5,sensation=5,NARRATIVE=5 & 0.11 & 0.92 & 1.57 \\
\hline$\{$ setting=Singleplayer,PROGRESSION=5,OBJECTIVES=5, sensation=5,NARRATIVE=5 & 0.10 & 0.95 & 1.63 \\
\hline$\{$ gender=Male,PROGRESSION=5,OBJECTIVES=5, sensation=5,NARRATIVE=5 $\}$ & 0.11 & 0.96 & 1.63 \\
\hline$\{$ gender=Male,setting=Singleplayer,OBJECTIVES=5, sensation=5,NARRATIVE=5 $\}$ & 0.10 & 0.95 & 1.62 \\
\hline$\{$ gender=Male,setting=Singleplayer,PROGRESSION=5,OBJECTIVES=5,NARRATIVE=5 $\}$ & 0.13 & 0.89 & 1.52 \\
\hline$\{$ gender=Male,setting=Singleplayer,PROGRESSION=5,sensation=5,NARRATIVE=5 $\}$ & 0.12 & 0.94 & 1.61 \\
\hline
\end{tabular}


VIII Congresso Brasileiro de Informática na Educação (CBIE 2019)

Anais do XXX Simpósio Brasileiro de Informática na Educação (SBIE 2019)

instructional design of content-focused gamified educational systems.

\section{Acknowledgment}

The authors would like to thank the funding provided by FAPESP (Projects 2018/159170; 2016/02765-2; 2018/11180-3; 2018/07688-1), CAPES and CNPq.

\section{References}

Adams, D. M., Mayer, R. E., MacNamara, A., Koenig, A., and Wainess, R. (2012). Narrative games for learning: Testing the discovery and narrative hypotheses. Journal of educational psychology, 104(1):235.

Agrawal, R., Imieliński, T., Swami, A., Agrawal, R., Imieliński, T., and Swami, A. (1993). Mining association rules between sets of items in large databases.

Augustine, S. (1876). The confessions. Clark.

Bogost, I. (2014). Gamification is Bullshit. In The Gameful World. The MIT Press, 1st edition.

Borges, S. d. S., Durelli, V. H. S., Reis, H. M., and Isotani, S. (2014). A systematic mapping on gamification applied to education. In Proceedings of the 29th Annual ACM Symposium on Applied Computing - SAC '14, number Icmc, pages 216-222.

Campbell, J. (2008). The hero with a thousand faces, volume 17. New World Library.

Champagnat, R., Delmas, G., and Augeraud, M. (2010). A storytelling model for educational games: Hero's interactive journey. International Journal of Technology Enhanced Learning, 2(1-2):4-20.

Chauvin, S., Levieux, G., Donnart, J.-Y., and Natkin, S. (2015). Making sense of emergent narratives: An architecture supporting player-triggered narrative processes. In 2015 IEEE Conference on Computational Intelligence and Games (CIG), pages 9198. IEEE.

Deterding, S., Khaled, R., Nacke, L. E., and Dixon, D. (2011a). Gamification: Toward a definition. CHI 2011 Workshop Gamification Research Network, pages 12-15.

Deterding, S., Sicart, M., Nacke, L., O'Hara, K., and Dixon, D. (2011b). Gamification. using game-design elements in non-gaming contexts. Proceedings of the 2011 annual conference extended abstracts on Human factors in computing systems - CHI EA '11, page 2425 .

Hamari, J., Koivisto, J., and Sarsa, H. (2014). Does Gamification Work? - A Literature Review of Empirical Studies on Gamification. 2014 47th Hawaii International Conference on System Sciences.

Hendrikx, M., Meijer, S., Van Der Velden, J., and Iosup, A. (2013). Procedural content generation for games: A survey. ACM Transactions on Multimedia Computing, Communications, and Applications (TOMM), 9(1):1.

Jenkins, H. (2006). Convergence culture: Where old and new media collide. NYU press.

Kapp, K. M. (2012). The Gamification of Learning and Instruction: Game-based Methods and Strategies for Training and Education. 
VIII Congresso Brasileiro de Informática na Educação (CBIE 2019)

Anais do XXX Simpósio Brasileiro de Informática na Educação (SBIE 2019)

Landers, R. N. (2014). Developing a theory of gamified learning: Linking serious games and gamification of learning. Simulation \& Gaming, 45(6):752-768.

Landers, R. N., Armstrong, M. B., and Collmus, A. B. (2017). How to use game elements to enhance learning: Applications of the theory of gamified learning. In Serious games and edutainment applications, pages 457-483. Springer.

Manimaran, J. and Velmurugan, T. (2015a). Analysing the quality of association rules by computing an interestingness measures. Indian Journal of Science and Technology, $8(15): 1-12$.

Manimaran, J. and Velmurugan, T. (2015b). Analysing the quality of association rules by computing an interestingness measures. Indian Journal of Science and Technology, $8(15): 1-12$.

Palomino, P. T., Toda, A. M., Oliveira, W., Cristea, A. I., and Isotani, S. (2019). Narrative for gamification in education: why should you care? In International Conference of Advanced Learning Techniques - Icalt 2019.

Preece, J., Rogers, Y., and Sharp, H. (2015). Interaction design: beyond human-computer interaction. John Wiley \& Sons.

Ricoeur, P. (2010). Time and narrative, volume 1. University of Chicago Press.

Salen, K., Tekinbaş, K. S., and Zimmerman, E. (2004). Rules of play: Game design fundamentals. MIT press.

Seaborn, K. and Fels, D. I. (2014). Gamification in Theory and Action: A Survey. Internatoinal Journal of Human-Computer Studies, 74:14-31.

Smith-Robbins, S. (2011). This Game Sucks: How to Improve the Gamification of Education. Educause Review, 46(1):58-59.

Tavakol, M. and Dennick, R. (2011). Making sense of cronbach's alpha. International journal of medical education, 2:53.

Toda, A. M., Oliveira, W., Klock, A. C., Palomino, P. T., Pimenta, M., Gasparini, I., Shi, L., Bittencourt, I., Isotani, S., and Cristea, A. I. (2019a). A taxonomy of game elements for gamification in educational contexts : Proposal and evaluation. In Conference on Advanced Learning Technologies and Technology-enhanced Learning 2019 (ICALT'19).

Toda, A. M., Oliveira, W., Shi, L., Bittencourt, I., Isotani, S., and Cristea, A. (2019b). Planning Gamification Strategies based on User Characteristics and DM : A Genderbased Case Study. In Proceedings of the Educational Data Mining 2019 conference, number i, pages 438 - 443, Montréal.

Toda, A. M., Valle, P. H. D. D., and Isotani, S. (2018). The Dark Side of Gamification: An Overview of Negative Effects of Gamification in Education. In Communications in Computer and Information Science, volume 832, pages 143-156. Springer, Cham.

Togelius, J., Kastbjerg, E., Schedl, D., and Yannakakis, G. N. (2011). What is procedural content generation?: Mario on the borderline. In Proceedings of the 2nd international workshop on procedural content generation in games, page 3. ACM. 